\title{
Antrenörlerin Mesleki Etik İlkelere Uyma Düzeylerinin Antrenör ve Sporcu Gözüyle Değerlendirilmesi
}

\section{An Evaluation by Trainers and Athletes of the Level of Conformity to Professional Ethics}

\author{
Zehra CERTEL * \\ Algin ALKIŞ ** \\ Bahri GÜRPINAR ${ }^{* * *}$
}

Öz: Meslek etiği ile ilgili olarak etik kod, etik ilke, etik dışı davranış, iş ahlakı, meslek ahlakı gibi kavramların son yıllarda oldukça fazla kullanıldığı görülmektedir. Birçok meslek dalında odluğu gibi antrenörlerin de etik ilkeleri belirlenmiş ve bu etik ilkelere uymaları beklenmektedir. Bu çalışmanın amac1, antrenörlerin mesleki etik ilkelere uyma düzeylerini antrenör ve sporcu görüşlerine göre değerlendirmektir. Araştırma, tarama modelindedir. Araştırmanın örneklemini, 2014 yllında Antalya ilinde çeşitli spor branşlarında görev yapan 144 antrenör (bireysel $=60$, takım=66, mücadele sporları $=18$ ) ve aktif olarak spora devam eden 229 sporcu (bireysel $=100$, takım=94, temaslı sporlar=35) olmak üzere toplamda 373 kişi oluşturmaktadır. Veri toplama aracı olarak Dolaşır-Tuncel ve Büyüköztürk (2009) tarafından geliştirilen “Antrenörlerin Mesleki Etik İlkeleri Ölçeği” kullanılmıştır. Sonuç olarak; antrenörlerin mesleki etik ilkelere uyma düzeyi antrenörlerin ve sporcuların cinsiyetlerine, eğitim düzeylerine ve yaptıkları spor dallarına göre farklılaşmamaktadır. Ayrıca antrenörlerin mesleki etik ilkelere uyma düzeyleri, sporcu ve antrenör görüşlerine göre anlamlı bir farkl1lık göstermektedir.

Anahtar sözcükler: Etik, Mesleki Etik İlkeleri, Antrenör, Sporcu

\begin{abstract}
Sport is a social phenomenon and a valuable cultural practice based on ethical foundation. The main objective of the sport ethics is to infuse accepted universal ethical principles in sport to individuals and to ensure these principles exhibited in the sport environment. The aim of this research is to evaluate the coaches' adherence to the professional ethic codes according to the views of coaches and athletes. There are 144 coaches (individual sports $=60$ team sports $=66$, combat sports $=18$ ) and 229 active athletes (individual sports $=100$ team sports $=94$, combat sports=35), totally 373 people from Antalya participated in the study. Coaches' Professional Ethics Code Scale developed by Dolaşır-Tuncel and Büyüköztürk (2009) is used as data collection tool. According to gender, there is no statistically significant difference in Professional Ethics Code scores of coaches and athletes. Also, according to the education level and sport type (individual and team) of coaches; coaches professional ethic code levels do not differ. According to the education level and sport type of athletes, coaches professional ethic code levels do not differ. According to position variable, compared to athletes, coaches mentioned that they adhere the ethical principles at a higher level.
\end{abstract}

Keywords: Ethics, Professional Ethics Codes, Coach, Athlete

\footnotetext{
* Doç. Dr., Akdeniz Üniversitesi, Spor Bilimleri Fakültesi, Beden Eğitimi ve Spor Eğitimi Bölümü, Antalya. zcertel@akdeniz.edu.tr

** Antalya Büyükşehir Belediyesi ASFIM Antrenörü, Antalya. alginalkis@gmail.com

*** Doç. Dr., Akdeniz Üniversitesi, Spor Bilimleri Fakültesi, Beden Eğitimi ve Spor Eğitimi Bölümü, Antalya. bahrigürpinar@akdeniz.edu.tr
} 


\section{Giriş}

Günümüzde meslek etiği ile ilgili olarak etik kod, etik ilke, etik dışı davranış, iş ahlakı, meslek ahlak1 gibi kavramlar sıklıkla kullanılmaktadır. "Felsefi bir disiplinin adı olan etik, köken olarak Hellence'deki ethos sözcügünden gelmekte olup doğru ve yanlış davranışları tanımlayan kurallar bütünü olarak kabul edilmekte ve bu etik kurallar bizlere davranışlarımızın kabul edilebilirliğini, kabul görmezliğini ve yanlışlığını belirtmektedir" (William et al. 1988). Her birey bir meslek grubuna aittir. Birçok meslek dalında etik ilkeler bulunmakta ve meslek üyelerinin söz konusu etik ilkelere uymaları beklenmektedir. Mesleki etik davranış, mesleği uygulamada doğru ve dürüst davranmaktır (Kultgen 1988). Pritchard (1988) ise meslek etiği ilkeleri, "genel ahlaki amaçlara dayalı, bir mesleğe üye insanların eylemlerine yol gösteren kısa yazılı kurallar" olarak tanımlamaktadır.

Spor, farklı boyutları, anlamları ve değerleri ile sosyal bilimlerde sıkça araştırmalara konu olmuştur. Erkal, Güven ve Ayan (1998), "spora sosyolojik olarak bakmanın; spor, sporcu ve başarı kavramlarının, toplumların var olmalarında diğer toplumlar ve kültürler arasında seçkin bir konuma gelmelerinde son derece önemli olduğunu" belirtmektedir. Çeşitli toplumlarda, inşanın fiziksel gelişiminin yanı sıra zihinsel, duygusal ve sosyal gelişimine de katkıda bulunan spor eğitimine oldukça önem verilmiştir (Özer 1990). Shields ve Bredemeier (1995), sporun ahlaki davranışların sergilendiği bir tiyatro olduğunu ve gerçekten de ahlaki gelişim üzerinde etkisinin var olduğunu belirtmişlerdir. Whithead (1998) ise "sporun etik temellere dayall ve değerli kültürel bir uygulama olduğu” üzerinde durmaktadır. "Spor tarihinin oluşumundan günümüze kadar spor topluluklarl, sporun kendisine ait bir takım etik davranışlara sahip olduğu ve bu davranışların sporun taraftarlarına kazandırllmasinın ve geliştirilmesinin önemli bir sorumluluk olduğuna inanmıslardır” (Bucher \& Wuest 1987). Bucher ve Wuest'e (1999) göre “spor etiğinin temel amacı, bireylere spor alanında kabul görmüş evrensel etik ilkeleri benimseterek, bu ilkelerin sportif ortamlarda davranış boyutunda sergilenmesini sağlamaktır." Sporda olumlu davranışların kazandırılmasında aracı olan antrenör, sporcunun başarısı için spor becerilerini ve gelişimini sağlamak için antrenörlük lisansı almış spor eğitimcisi olarak tanımlanabilir. Vanek (1971), antrenörü, "teknisyen olarak gerekli bilgileri, bilimin ışı̆̆ında sporcunun başarısı için kullanan, daha sonra bu bilgileri spor becerileri ve stratejiler ile birleştiren ve farklı mizaçlardaki insanlara uygulayabilen kişi olarak tanımlarken, antrenörün iyi bir organizatör, etkili bir yönetici, motive edici ve sporcuya bağımsızlığını, yeterliliğini kazandıran bir eğitimci olması gerektiği de" vurgulamıştır. Brighton Üniversitesi, Köln Alman Spor Üniversitesi ve İngiliz Konseyi'nin ortaklaşa düzenledikleri bir proje olan Uluslararası Barış İçin Futbol (F4P) programında, İsrail ve Filistinli çocukları futbol ile kaynaştırmak hedeflenmiş ve bu projede değerlerin sporculara aktarılmasında antrenörlerin önemli bir görevi olduğu belirtilmiş ve program sonunda hem antrenörlerin hem de sporcuların saygı, sorumluluk, güven, tarafsılık ve eşitçe kat1lım değerlerinde olumlu değişimler meydana geldiği gözlenmiştir (Lambert 2016).

Birçok uluslararası spor komiteleri ve birlikleri "antrenörlerin saygı, dürüstlük, tarafsızlık, adalet gibi evrensel değerler doğrultusunda yerine getirmelerine rehberlik edecek antrenörlük etik ilkeleri” belirlemişlerdir. Bu ilkeler incelendiğinde; dil, din, ırk, yaş ve cinsiyet gibi ayrımlar yapmadan sporcuları tehlikeden koruma sorumluluğunu almaları, antrenörlük yetkisini kötüye kullanmamaları, harcamaları dürüstlük çerçevesinde yapmaları, ilaç kullanma konusunda sporculara tolerans göstermemeleri, antrenör imajına saygı duyarak her türlü iletişimde ve ilişkide yüksek standartta davranışlarda bulunmaları gerektiği ve antrenörlüğü bir uzmanlık alanı olarak görüp, antrenörlük ilkelerine uygun hareket ederek, toplumdaki antrenörlük algısına zarar vermemeleri, uzmanlık, deneyim ve becerilerini abartmamaları, çalıştıkları bireylere saygı duy- 
maları konuları üzerinde durdukları görülmektedir (Mackenzie 2001; Sevim et al. 2001; Lyle 2002; International Coach Federation 2003). Antrenörlerin meslek etik ilkelerini benimsemeleri ve bu ilkeleri davranışlarında göstermeleri gerekmektedir. Antrenörlerin davranışlarına yol gösteren etik ilkeleri bilmeleri noktasında eğitim büyük önem taşımaktadır.

Alanyazın taramasında etik konusunda müfettiş ve beden eğitimi öğretmenleri üzerinde yapılan birçok çalışmaya rastlanmıştır (Janelle \& Taylor 1994, Kıranlı 2002, Özbek 2003, Kahraman 2003). Çalışma konusuyla ilgili olarak ise Gürpınar (2009), basketbol ve futbol hakemlerinin gözünden antrenörlerin yaptıkları sportmenlik dışı davranışları incelemiş ve sportmenlik dışı davranışları en çok seyircilerin en az da antrenörlerin de içinde bulunduğu teknik ekibin gerçekleştirdiğini belirtmiştir.. Karakoç, Yüksel, Aydın, Karakoç, Yetiş ve Baydil (2011) 54 judocu üzerinde yaptıkları çalışmada sporcuların antrenörlerinde gözlemledikleri etik dışı davranışları saptamışlardır. Eskicioğlu, Doğu ve Özsoy (2012) ise BEKO Basketbol Ligi’nde antrenör ve sporcu bakış açısıyla kendi yöneticilerinin aldıkları kararlarda etik ilkelere bağlılık düzeyini belirlemeye yönelik bir çalışma gerçekleştirmişlerdir. Gürkan ve Şişman, (2015) Sırbistan'ın Kızılyıldız takımı ile Galatasaray arasında oynanan basketbol maçını spor medyasındaki etik düzleme göre tartışmışlardır. Dolaşır (2005) ve Dolaşır-Tuncel ve Büyüköztürk (2009) ise antrenör mesleki etik ölçeği geliştirerek millî takım kampında bulunan sporcu ve antrenörün mesleki etik ilkelere uyma düzeylerini belirlemişlerdir. Güven ve Öncü (2012) çalışmalarında antrenörlerdeki etik dışı davranışlarını sporcu algılarına göre belirlemek için bir ölçek geliştirmişlerdir.

Son zamanlarda sporun amacından saptırılarak maddi çıkara bir araç olarak kullanılması spor etiğine olan ihtiyacı ortaya koymaktadır. Sporun temel taşı olan antrenörlerin etik ilkelerine uyma düzeylerinin belirlenmesi ve belirlenen eksikliklerin giderilmesi amacıyla çalışmaların yapılması gerektiği görülmektedir. Yukarıdaki çalışmalara bakıldığında antrenörlerin mesleki etik ilkelerine yönelik çalışmalarının millî takım antrenör ve sporcuları üzerinde yoğunlaştığı göze çarparken, temel eğitim antrenörleriyle ilgili yapılan çalışmaya rastlanmamıştır. Bu bağlamda araştırmada Antalya ilinde bulunan ve çeşitli branş ve kulüplerde görev yapan antrenörlerin meslek etiği ilkelerine uyma düzeyleri belirlenerek antrenör ve sporcu gözüyle değerlendirilmesinin alana katkı sağlayacağı düşünülmüştür.

\section{Yöntem}

Antrenörlerin görev ve sorumluluklarına ilişkin mesleki etik ilkelerine uyma düzeylerini antrenör ve sporcu görüşlerine göre değerlendirmeyi amaçlayan bu çalışmada, var olan bir durumu, var olduğu haliyle betimlemeyi amaçlayan tarama modeli kullanılmıştır.

\section{Araştırma Grubu}

Araştırma verileri 2014-2015 y1lında toplanmıştır. Araştırmaya Antalya ilinde çeşitli branşlarda görev yapan 144 antrenör ve aktif spora devam eden 229 sporcu olmak üzere 373 kişi katılmıştır. Sporcuların 103'ü kadın, 126'sı erkektir. Antrenörlerin 54'ü kadın, 90'1 erkektir. Sporcuların yaş ortalamas $(\bar{X}=22.47 \pm 4.02)$ y1l ve sporculuk deneyimi $(\bar{X}=4.76 \pm 3.08)$ y1ldır. Antrenörlerin yaş ortalaması $(\bar{X}=35.12 \pm 9.75)$ yıl ve antrenörlük deneyimi $(\bar{X}=10.60 \pm 7.38)$ yıldır. Sporcuların branşları, halk oyunları $(n=45, \% 12.1)$, voleybol $(n=25, \% 6.7)$, hentbol $(n=25, \% 6.7)$, futbol $(n=35, \% 9.4)$, basketbol $(n=30, \% 8.0)$, güreş $(n=15, \% 4.0)$, karate $(n=22, \% 5.9)$, muaythai $(\mathrm{n}=16, \% 4.3)$, badminton $(\mathrm{n}=15, \% 4.0)$, tenis $(\mathrm{n}=30, \% 8.0)$, okçuluk $(\mathrm{n}=15, \% 4.0)$, atletizm $(n=25, \% 6.7)$, yüzme $(n=35, \% 9.4)$, fitness $(n=25, \% 6.7)$, bisiklet $(n=15, \% 4.0)$ şeklindedir. İlerleyen bölümlerdeki analizlerde sporcu branşları birleştirilerek, takım sporları (halk oyunları, voleybol, hentbol, futbol, basketbol), bireysel sporlar (badminton, tenis, okçuluk, atletizm, 
yüzme, fitness, bisiklet) ve mücadele sporları (güreş, karate, muaythai) olarak alınmıştır.

\section{Veri Toplama Araçları}

Veriler "Antrenörlerin Mesleki Etik İlkeleri Ölçeğì" (AMEïÖ) ve araştırmacı tarafından oluşturulan kişisel bilgi formu aracıllı̆̆ ile toplanmıştır.

Antrenörlerin Mesleki Etik İlkeleri Ölçeği (AMEİÖ): Ölçek Dolaşır Tuncel ve Büyüköztürk (2009) tarafindan geliştirilmiştir. Orijinal ölçek 44 antrenör ve 160 sporcu üzerinde geliştirilmiş olup 34 maddeye sahip ve beşli likert şeklindedir. Ölçek, saygı (örnek madde: "Her bir sporcunun varliğına saygı duyar") ve sorumluluk (örnek madde: "Sporu koruma ve geliştirme sorumluluğuna sahiptir") olmak üzere iki alt boyuta sahiptir. Sorumluluk boyutu 21 madde, sayg1 boyutu ise 13 maddeden oluşmaktadır. Ölçeğin faktör yapısını belirlemek için, Açımlayıcı Faktör Analizi (AFA) ve doğrulayıcı Faktör Analizi (DFA) yapılmıştır. DFA sonucunda uyum indeksleri $\chi 2=1272,24(\mathrm{sd}=525, \mathrm{p}<.001),(\chi 2 / \mathrm{sd})=2.42, \mathrm{RMSEA}=0.08, \mathrm{RMS}=0.03$, SRMS $=0.05$, $\mathrm{GFI}=0.73$ ve $\mathrm{AGFI}=0,69$ olarak bulunmuştur. Ölçekteki tüm maddelerin madde-toplam korelasyon değerlerinin .553 ile .799 arasında değiştiği görülmüştür. Orijinal Ölçeğin Cronbach’s Alfa Güvenirlik Katsayıs1 .97 olarak bulunmuşken, bu araştırmada Cronbach’s Alfa Güvenirlik Katsayısı .96 olarak hesaplanmıştır.

\section{Verilerin Analizi}

$\mathrm{Bu}$ araştırmaya ait verilerin istatistiksel analizleri SPSS 18.00 paket programı ile yapılmıştır. Araştırmada verilerin analizinde kişisel bilgiler için betimsel istatistik yöntemleri olarak frekans (n), yüzde (\%), aritmetik ortalama $(\bar{X})$ ve standart sapma (Ss) kullanılmıştır. Araştırmada verilerin dağılımını incelemek için Kolmogorow Smirnow testi yapılmıştır. Veriler normal dağılım göstermediği için ikili karşılaştırmalarda (cinsiyet, eğitim düzeyi ve antrenör ve sporcu olma durumunda) Mann Whitney U testi, çoklu karşılaştırmalarda (antrenör ve sporcuların spor dallarına göre) ise Kruskall Wallis testi kullanılmıştır.

\section{Süreç}

Araştırmacı Antalya ilinde çeşitli spor branşında faaliyet gösteren spor kulüplerinin antrenman programını almış ve o saatlerde ölçekleri uygulamak için antrenman yapılan yerlere gitmiştir. Antrenörlere araştırmanın amacına ilişkin kısa bir bilgi verilmiş ve ardından gönüllük ilkesi esas alınarak araştırmaya katılmak isteyen antrenöre ölçekler dağıtılmıştır. Sporculara ise antrenöründen izin alınarak ölçekler uygulatılmıştır. Ayrıca gerekli durumlarda katılımcılara ek açıklamalar yapılmıştır. Katılımcılardan kimlik bilgileri istenmemiştir.

\section{Bulgular}

Araştırmada kullanılan ölçekte antrenörler için 34 mesleki etik ilke belirlenmiştir. Sporcular; antrenörlerinin mesleki etik ilkeler içinde "Sporcularına kazanmanın iyi bir takım çalışmasının sonucu olduğunu benimsetir" ( $\overline{\mathrm{X}}=4.01 \pm 85)$, "Yarlşma kurallarına saygllıdır " $(\overline{\mathrm{X}}=4.01 \pm .85)$ ve "Sporu koruma ve geliştirme sorumluluğuna sahiptir" ( $(\overline{\mathrm{X}}=4.01 \pm .83)$ ilkelerine diğer ilkelere göre daha yüksek düzeyde uyduklarını belirtirken "Yarlşma ve antrenmanlarda güvenli bir çevre sağlar" ( $\overline{\mathrm{X}}=3.66 \pm .97)$, "Sporcular ve aileleri ile sporcuların takım içerisindeki hak ve sorumluluklart ile ilgili iletişim kurar" $(\overline{\mathrm{X}}=3.68 \pm 1.00)$ ve "Sporcularına sporun yanı sıra eğitimin önemini de vurgular" ( $\overline{\mathrm{X}}=3.85 \pm .82)$ ilkelerine en düşük düzeyde uyduklarını belirtmişlerdir.

Antrenörler ise mesleki etik ilkeler içinde "Diğer antrenör ve kulüpleri eleştirirken küçültücü ifadeler kullanmaz" ( $\overline{\mathrm{X}}=4.57 \pm .54)$, "Sporu koruma ve geliştirme sorumluluğuna sahiptir" 
( $\overline{\mathrm{X}}=4.53 \pm .59)$, “Sahip olduğu yeterlilikleri abartmaz" $(\overline{\mathrm{X}}=4.53 \pm .59)$, ilkelerine diğer ilkelere göre en yüksek düzeyde uyduklarını belirtirken "Profesyonel olmayan sporculardan antrenman için talep ettiği süre sporcuların ögrenimleri ve akademik gelişimleri için ayrılan süreyi etkilemez" ( $\overline{\mathrm{X}}=4.14 \pm .81)$ ve "Yarışma ve antrenmanlarda güvenli bir çevre sağlar" ( $\overline{\mathrm{X}}$ $=4.28 \pm .60)$ ilkelerine en düşük düzeyde uyduklarını belirtmişlerdir. Çalışmada 34 sorudan oluşan ankete sporcuların verdikleri yanıtların ortalaması $(\overline{\mathrm{X}}=3.54 \pm .51)$, antrenörlerin verdikleri yanitların ortalaması $(\bar{X}=4.03 \pm .30)$ ve antrenör ve sporcuların birlikte verdikleri yanttların ortalaması ( $\overline{\mathrm{X}}=3.73 \pm .50)$ olarak bulunmuştur. Tablo 1'de antrenör ve sporcuların cinsiyetlerine göre meslek etik ölçeği puanlarının Mann Whitney-U testi sonuçları yer almaktadır.

Tablo 1. Antrenör ve Sporcuların Cinsiyetlerine Göre Mesleki Etik İlkeleri Ölçeği (AMEïÖ) Puanlarının Mann Whitney-U Testi Sonuçları

\begin{tabular}{|c|c|c|c|c|c|c|}
\hline Faktör & Görev & Cinsiyet & $\mathbf{n}$ & Sira ort. & $\mathbf{U}$ & $\mathbf{p}$ \\
\hline \multirow{4}{*}{ Sorumluluk } & Sporcu & Kadın & 103 & 113.05 & & \\
\hline & & Erkek & 126 & 116.60 & -.403 & .687 \\
\hline & Antrenör & Kadın & 54 & 69.28 & & \\
\hline & & Erkek & 90 & 74.43 & -.722 & .470 \\
\hline \multirow{4}{*}{ Saygı } & Sporcu & Kadın & 103 & 109.60 & & \\
\hline & & Erkek & 126 & 119.42 & -1.117 & .264 \\
\hline & Antrenör & Kadın & 54 & 67.37 & & \\
\hline & & Erkek & 90 & 75.58 & -1.152 & .249 \\
\hline \multirow{4}{*}{ AMEİÖ } & Sporcu & Kadın & 103 & 112.94 & & \\
\hline & & Erkek & 126 & 116.68 & -.596 & .551 \\
\hline & Antrenör & Kadın & 54 & 68.98 & & \\
\hline & & Erkek & 90 & 74.61 & -.786 & .432 \\
\hline
\end{tabular}

Tablo 1 incelendiğinde ölçeğin sorumluluk alt boyutunda, sporcuların $(U=-.403, p=.687 ; p>.05)$ ve antrenörlerin cinsiyetlerine göre $(U=-.722, \mathrm{p}=.470 ; \mathrm{p}>.05)$ puan sıra ortalamaları arasında istatistiksel olarak anlamlı bir fark bulunmamıştır. Ölçeğin sayg1 alt boyutunda, sporcuların $(\mathrm{U}=-1.117, \mathrm{p}=.264 ; \mathrm{p}>.05)$ ve antrenörlerin cinsiyetlerine göre $(\mathrm{U}=-1.152, \mathrm{p}=.249 ; \mathrm{p}>.05)$ puan sıra ortalamaları arasında istatistiksel olarak anlamlı bir fark bulunmamıştır. Antrenörlerin mesleki etik ilkeleri ölçeğinde (AMEIÖ), sporcuların ( $U=-.596, p=.551 ; p>.05)$ ve antrenörlerin $(\mathrm{U}=-.786, \mathrm{p}=.432 ; \mathrm{p}>.05)$ cinsiyetlerine göre puan sira ortalamaları arasında istatistiksel olarak anlamlı bir fark bulunmamıştır. Tablo 2'de antrenör ve sporcuların eğitim düzeylerine göre mesleki etik ilkeleri ölçeği puanlarının Mann Whitney U testi sonuçları yer almaktadır.

Tablo 2 incelendiğinde sporcuların eğitim durumlarına göre sorumluluk $(U=-1.407, p=.159$; $\mathrm{p}>.05)$, saygı ( $\mathrm{U}=-.851, \mathrm{p}=.395 ; \mathrm{p}>.05)$ boyutlarında ve ölçek toplamında $(\mathrm{U}=-1.174, \mathrm{p}=.240$; $\mathrm{p}>.05)$ puan sıra ortalamaları arasında istatistiksel olarak anlamlı bir farklılık bulunmamıştır. Aynı şekilde antrenörlerin eğitim durumlarına göre de sorumluluk ( $U=-.028, p=.978 ; p>.05)$, sayg1 ( $U=-1.294, p=.196 ; p>.05)$ boyutlarında ve ölçek toplamında $(U=-531, p=.596 ; p>.05)$ AMEİÖ puan sıra ortalamaları arasında istatistiksel olarak anlamlı bir farklılık bulunmamıştır.

Tablo 2. Antrenör ve Sporcuların Eğitim Düzeylerine Göre Mesleki Etik İlkeleri Ölçeği Puanlarının Mann Whitney-U Testi Sonuçları

\begin{tabular}{lllllll}
\hline Faktör & Görev & Eğitim düzeyi & $\mathbf{n}$ & Sura ort. & U & P \\
\hline \multirow{3}{*}{ Sorumluluk } & Sporcu & Lise & 149 & 110.09 & & \\
& & Üniversite & 89 & 122.72 & -1.407 & .159 \\
\cline { 2 - 7 } & Antrenör & Lise & 49 & 72.63 & & \\
& & Üniversite & 95 & 72.43 & -.028 & .978 \\
\hline & Sporcu & Lise & 149 & 112.03 & & \\
\hline
\end{tabular}




\begin{tabular}{lllllll}
\hline Saygı & & Üniversite & 89 & 119.67 & -.851 & .395 \\
\cline { 2 - 6 } & Antrenör & Lise & 49 & 66.29 & & \\
& & Üniversite & 95 & 75.71 & -1.294 & .196 \\
\hline \multirow{3}{*}{ AMEİ̈ } & Sporcu & Lise & 149 & 110.90 & & \\
& & Üniversite & 89 & 121.44 & -1.174 & .240 \\
\cline { 3 - 7 } & Antrenör & Lise & 49 & 69.94 & & \\
& & Üniversite & 95 & 73.82 & -.531 & .596 \\
\hline
\end{tabular}

Tablo 3'te antrenörlerin spor dallarına göre meslek etik ilkeleri ölçeği puanlarının karşılaştırılması verilmiştir.

Tablo 3. Antrenör ve Sporcuların Spor Dallarına Göre Mesleki Etik İlkeleri Ölçeği Puanlarının Kruskall Wallis Testi Sonuçları

\begin{tabular}{|c|c|c|c|c|c|c|}
\hline Faktör & Görev & Branş & n & Sira ort. & $\chi^{2}$ & $\mathbf{p}$ \\
\hline \multirow{6}{*}{ Sorumluluk } & Sporcu & Bireysel & 100 & 123.03 & \multirow{3}{*}{2.928} & \multirow{3}{*}{.231} \\
\hline & & Takım & 94 & 106.77 & & \\
\hline & & Mücadele & 35 & 114.17 & & \\
\hline & Antrenör & Bireysel & 60 & 67.21 & \multirow{3}{*}{3.180} & \multirow{3}{*}{.204} \\
\hline & & Takım & 66 & 79.18 & & \\
\hline & & Mücadele & 18 & 65.64 & & \\
\hline \multirow{6}{*}{ Saygı } & Sporcu & Bireysel & 100 & 126.13 & \multirow{3}{*}{5.079} & \multirow{3}{*}{.079} \\
\hline & & Takım & 94 & 105.50 & & \\
\hline & & Mücadele & 35 & 108.73 & & \\
\hline & Antrenör & Bireysel & 60 & 66.33 & \multirow{3}{*}{2.918} & \multirow{3}{*}{.232} \\
\hline & & Takım & 66 & 78.78 & & \\
\hline & & Mücadele & 18 & 70.03 & & \\
\hline \multirow{6}{*}{ AMEİÖ } & Sporcu & Bireysel & 100 & 124.45 & \multirow{3}{*}{3.731} & \multirow{3}{*}{.155} \\
\hline & & Takım & 94 & 106.46 & & \\
\hline & & Mücadele & 35 & 110.93 & & \\
\hline & Antrenör & Bireysel & 60 & 67.44 & \multirow{3}{*}{2.989} & \multirow{3}{*}{.224} \\
\hline & & Takım & 66 & 78.98 & & \\
\hline & & Mücadele & 18 & 65.58 & & \\
\hline
\end{tabular}

Tablo 3 incelendiğinde sporcuların spor dallarına göre sorumluluk $\left(\chi^{2}=2.928, \mathrm{p}=.231 ; \mathrm{p}>.05\right)$, sayg1 $\left(\chi^{2}=5.079, \mathrm{p}=.079 ; \mathrm{p}>.05\right)$ boyutlarında ve ölçek toplamında $\left(\chi^{2}=3.731, \mathrm{p}=.155 ; \mathrm{p}>.05\right)$ AMEİÖ puan sıra ortalamaları arasında istatistiksel olarak anlamlı bir farklılık bulunmamıştır. Aynı şekilde antrenörlerin eğitim durumlarına göre de sorumluluk $\left(\chi^{2}=3.180, p=.204 ; \mathrm{p}>.05\right)$, saygı $\left(\chi^{2}=2.918, \mathrm{p}=.232 ; \mathrm{p}>.05\right)$ boyutlarında ve ölçek toplamında $\left(\chi^{2}=2.989, \mathrm{p}=.224 ; \mathrm{p}>.05\right)$ AMEIOO puan sıra ortalamaları arasında istatistiksel olarak anlamlı bir farklılık bulunmamıştır. Katılımcıların antrenör ve sporcu olma durumuna göre mesleki etik ilkeleri ölçeğinden aldıkları puanların Mann Whitney-U testi sonuçları tablo 4'de verilmiştir.

Tablo 4. Antrenör ve Sporcu Olma Durumuna Göre Meslek Etik Ölçeğinden Alınan Puanların Mann Whitney-U Testi Sonuçları

\begin{tabular}{llllll}
\hline Ölçek & Görev & n & Sira ort & U & p \\
\hline Sorumluluk & Sporcu & 229 & 139.03 & & \\
& Antrenör & 144 & 263.28 & $-10.848^{*}$ & .000 \\
\hline Saygı & Sporcu & 229 & 144.95 & & \\
& Antrenör & 144 & 253.86 & $-9.520^{*}$ & .000 \\
\hline AMEİÖ & Sporcu & 229 & 138.41 & & \\
& Antrenör & 144 & 264.26 & $-10.982^{*}$ & .000 \\
\hline
\end{tabular}

$* \mathrm{P}<.05$ 
Tablo 4 incelendiğinde antrenör ve sporcu olma durumuna göre mesleki etik ölçeğinin sorumluluk ( $\mathrm{U}=-10.848, \mathrm{p}=.000 ; \mathrm{p}<.05)$ ve sayg1 $(\mathrm{U}=-9.520, \mathrm{p}=.000 ; \mathrm{p}<.05)$ boyutlarında ve ölçek toplamında $(\mathrm{U}=-10.982, \mathrm{p}=.000 ; \mathrm{p}<.05)$ alınan puan sira ortalamalar1 arasında istatistiksel olarak anlamlı bir ilişki bulunmuştur. Burada sporcu başlığındaki puan sporcuların antrenörleri değerlendirme puanı iken antrenör başlığındaki puan antrenörlerin kendilerini değerlendirme puanıdır. Antrenörler sorumluluk, saygı alt boyutlarında ve ölçek toplamında sporcuların antrenörleri hakkındaki görüşleriyle karşılaştırıldığında mesleki etik ilkelere daha yüksek seviyede uyduklarını belirtmişlerdir.

\section{Tartışma Sonuç ve Öneriler}

Bu çalışmada antrenörlerin mesleki etik ilkelere uyma düzeylerini belirlemek için antrenörlerin kendi öz-değerlendirmelerini yapmaları aynı zamanda sporcuların kendi antrenörlerini değerlendirmeleri istenerek karşılaştırma yapılması amaçlanmıştır. Buna göre aşağıdaki sonuçlara ulaşılmıştır:

Araştırmaya katılan antrenör ve sporcuların ölçeğe verdiği yanıtların ortalamasına göre antrenörlerin mesleki etik ilkelere ortalamanın üstünde uygun davrandıkları sonucu çıkarılabilir ( $\bar{X}=3.73 \pm .50)$. Nitekim Karakoç et al. (2011), millî judocular üzerinde yaptıkları araştırmada da sporcuların bakış açıları ile antrenörlerin etik dışı davranışlarını belirlemeye çalışmışlar ve antrenörlerin genel olarak etik kurallar çerçevesinde davrandığı sonucuna ulaşmışlardır. Çalışmamızı destekler niteliktedir.

Antrenörlerin mesleki etik ilkelere uyma düzeyleri; sporcuların cinsiyetlerine, lise veya üniversite mezunu olma durumlarına ve bireysel, takım ve mücadele sporları yapma durumlarına göre farklılaşmamaktadır. Dolaşır'ın (2005) ve Güven ve Öncü'nün (2012) yaptıkları çalışmalarda da sporcuların cinsiyetlerine göre antrenörlerinin mesleki etik ilkelere uyma düzeyi farkl1laşmamaktadır. Ancak Dolaşır Tuncel ve Büyüköztürk'ün (2009) millı̂ sporcu ve antrenörler üzerinde yaptıkları araştırmada; kadın sporcuların erkek sporculara göre antrenörlerinin etik ilkelere uyma düzeylerini daha yüksek buldukları belirtilmiştir. Bu araştırmada ise kadın ve erkek sporcular; antrenörlerinin mesleki etik ilkelere benzer düzeyde uyduklarını belirtmişlerdir. Dolaşır'ın (2005) çalışmasında, üniversite ve üstü mezunu olan sporcuların lise mezunu sporculara göre antrenörlerinin etik ilkelere daha az uyduğunu ve ikili spor branş sporcuları, bireysel spor branş sporcularına göre antrenörlerinin etik ilkelere daha yüksek düzeyde uyduklarını belirtmişlerdir. Yapılan çalışmalar millî takım düzeyinde yapıldığı için bu farklılığın örneklem grubundan kaynaklandığg söylenebilir.

$\mathrm{Bu}$ araştırmada antrenörlerin cinsiyetlerine, lise veya üniversite mezunu olma durumlarına ve bireysel, takım mücadele sporları antrenörü olma durumlarına göre mesleki etik ilkelere uyma düzeylerine ilişkin görüşleri farklılık göstermemektedir. Dolaşır Tuncel ve Büyüköztürk'ün (2009) yaptığı çalışmada, erkek antrenörler kadın antrenörlere göre etik ilkelere uyma düzeylerinin daha yüksek olduğunu belirtmişlerdir. Dolaşır (2005) çalışmasında antrenörlerin cinsiyetlerinin, branşlarının ve eğitim durumlarının onların mesleki etik ilkelere uyma düzeylerini etkilemediği sonucuna varmıştır. Bu sonuçlar araştırmamızı destekler niteliktedir.

Antrenörlerin mesleki etik ilkelere uyma düzeylerinde, antrenörün ve sporcularının bakış açısına göre anlamlı bir farklılık bulunmaktadır. Sporcuların kendi antrenörlerinin mesleki etik davranışlarına verdikleri puan ortalamaları ile antrenörlerin kendi etik davranışlarına verdikleri (öz değerlendirme) puan ortalamaları arasındaki fark istatistiksel olarak anlamlı bulunmuştur. Yani antrenörler kendilerini daha etik bulmakta; sporcuları ise antrenörlerini o kadar etik bulmamaktadırlar. Özbek'in (2003) beden eğitimi öğretmenleri üzerinde ve Dolaşır (2005) ve 
Dolaşır-Tuncel ve Büyüköztürk'ün (2009) millî sporcular üzerinde yaptıkları çalışmalarda da benzer sonuçlar bulunmuştur. Bireyin kendini değerlendirmesiyle, dışarıdan birinin bireyi değerlendirmesi arasında elbette bir farkın olması beklenebilir. Kişinin kendisini nesnel olarak değerlendirmesinin oldukça zor olduğu söylenebilir.

Sonuç olarak; günümüzde sporun temel taşı olan antrenörlerin etik dışı davranışta bulunması antrenörlerin ve sporun saygınlığını azaltmaktadır. Antrenörlere mesleki etik ilkeleri benimsetmek sporun saygınlığının artmasına ve istenilen düzeye erişmesine katkı sağlayacaktır. Antrenörlere mesleki etik ilkeleri benimsetirken, Cushion, Armaur ve Joney (2003) "değişik spor dallarında yetiştirilecek antrenörlerin spor dalının özelliği dikkate alınarak bir model içinde eğitilmesi ve gelişstirilmesinin bir zorunluluk" olduğunu belirtmektedir. Spor Bilimleri Fakülteleri ve Beden Eğitimi ve Spor Yüksekokulu Antrenör Eğitimi Bölümlerinde ve Spor Eğitim Dairesi tarafından düzenlenen Antrenör Eğitimi Kurslarının ders programlarına meslek etiği dersinin yer almasının antrenörlerin mesleki etik ilkelerini bilmesi ve dolayısıyla sergilemesi açısından önemli olduğu düşünülmektedir. Araştırma önerisi olarak bu çalışma değişik illerde büyük örneklem gruplarında ve çeşitli spor branşları tek tek ele alınarak millî takım ve alt yapı düzeyinde yapılabilir. Ek olarak farklı antrenör tipleri ile mesleki etik davranışlar arasındaki ilişki incelenebilir.

\section{Yazarın Notu}

Bu çalışma; 18-20 Kasım 2016'da Elazığ'da düzenlenen 10. Uluslararası Beden Eğitimi, Spor ve Fiziksel Terapi Kongresi'nde (ICPESPT2016) poster bildiri olarak sunulmuştur.

\section{KAYNAKÇA}

Bucher C. A., \& Wuest D. A. (1987). Foundation of Physical Education and Sport. Santa Clara 1987.

Cushion C. J., Armour K. M., \& Jones R. L. (2003). "Coach Education and Continuing Professional Development”. Experiences and learning to Coach, Quest 5 (2003) 215-230.

Dolaşır S. (2005). Antrenörlerin Mesleki Etik İlkelere Uyma Düzeylerine İlişkin Antrenör ve Sporcu Görüşleri. Yayımlanmamış Doktora Tezi. Ankara Üniversitesi. Ankara 2005.

Dolaşır-Tuncel S. \& Büyüköztürk Ş. (2009). “Antrenörlerin Mesleki Etik İlkeleri Nelerdir? Nasıl Ölçülür? Ölçek Geliştirme: Ölçeklerin Geçerlik ve Güvenirliği”. Spormetre Beden Eğitimi ve Spor Bilimleri Dergisi VII/4 (2009) 159-168.

Erkal M., Güven Ö. \& Ayan D. (1998). Sosyolojik Açıdan Spor. İstanbul 1998.

Eskicioğlu Y. E., Doğu G. \& Özsoy S. (2012). “Antrenör ve Sporcu Gözüyle Spor Yöneticilerinin Kararlarında Etik İlkelere Bağlllıklarının İncelenmesi (BEKO Basketbol Ligi Örneği)”. İ.Ü. Spor Bilim Dergisi 4 (2012) 13-22.

Gürkan H. \& Şişman B. (2015). "Etik Düzlem Çerçevesinde Spor Medyası: Sırbistan Kızılyıldız-Türkiye Galatasaray Basketbol Maçı”. Akademik Sosyal Araştırmalar Dergisi 14 (2015) 176-193.

Gürpınar B. (2009). Basketbol ve Futbol Hakemlerinin Karşılaş̧ıkları Sportmenlik Dışı Davranışlar ve Bu Davranışların Çeşitti Değiş̧kenler Açısından İncelenmesi. Yayımlanmamış Doktora Tezi. Gazi Üniversitesi. Ankara 2009.

Güven Ö. \& Öncü E. (2012). “Antrenörlerin Etik Dış1 Davranışları ile İlgili Sporcu Algısı Ölçeğinin Geliştirilmesi”. SPORMETRE Beden Eğitimi ve Spor Bilimleri Dergisi X/2 (2012) 67-75.

International Coaches Federation (2003). "ICF Standart of Ethical Conduct. Retrieved October 25". Adopted by the ICF Global Board of Directors June 2015. Source: <http//www.icfoffice@coach federation.org $>$.

Janelle K. \& Taylor G. (1994). “A Code Of Ethics For Physical Education Majör”. Physical Educator 
51/3 (1994) 144-148.

Kahraman N. (2003). Illköğretim Müfettişlerinin Mesleki Etik İlkeleri ve Bu İlkelere Uyma Düzeyleri. Yayımlanmamış Doktora Tezi. Ankara Üniversitesi. Ankara 2003.

Karakoç Ö., Yüksek S., Aydın A. D., Karakoç B., Yetiş Ü. \& Baydil B. (2011). "Millî Takım Düzeyindeki Erkek Judocuların Kulüp Antrenörlerinde Gözlemledikleri Etik Dışı Davranışlar”. Kastamonu Eğitimi Dergisi 19/1 (2011) 321-332.

Kıranlı S. (2002). Ortä̈ğretim Yöneticilerinin Etik İlkelere Uyma ve Etik İkilemleri Çözümleme Yeterliliği. Yayımlanmamış Doktora Tezi. Osmangazi Üniversitesi. Eskişehir 2002.

Kultgen J. (1998). Ethics and Professionalizm. Pennslyvania 1998.

Lambert J. (2016). “Antrenör Davranışları Motivasyonel İklimi Nasıl Değiştirir?”. Eds. J. Whitehead, H. Telfer \& J. Lambert, Altyapı Sporlarında ve Beden Eğitiminde Değerler (2016) 166-177. Ankara.

Lyle J. (2002). Sports Coaching Concepts: A Framework Fr Coaches’ Behaviour. London 2002.

Mackenzie B. (2001). British Athletics - Code of ethics for Coaches [WWW] Source: <https:// www.brianmac.co.uk/ukethics.htm>.

Özbek Ö. (2003). Beden Eğitimi Öğretmenlerinin Mesleki Etik İlkeleri ve Bu İlkelere Uyma Düzeyleri. Yayımlamamış Doktora Tezi. Ankara Üniversitesi. Ankara 2003.

Özer K. (1990). Sporda Eğitimi ve Öğretim. Spor Şurası Bildirileri. Ankara 1990.

Pritchard J. (1988). Codes of Ethics: Encyclopedia of Applied Ethics. 1. Colifornia 1988.

Sevim Y., Tuncel F., Erol E. \& Sunay H. (2001). Antrenör Eğitimi ve İlkeleri. Ankara 2001.

Shields D. L. L. \& Bredemeier B. J. L. (1995). Character Development and Physical Activity. Champaign 1995.

Vanek M. (1971). The Coaches' Role and Attitutes Proceedings of International Symposium on the Art and Science of Coaching. Canada 1971.

Whithead M. (1998). “Sport Ethics and Education”. Sport Education And Society 3/2 (1998) 239-241.

William C., Davis K. \& Post E.J. (1988). Business and Society, Corporate Strategy, Publicly, Ethics. USA 1988. 